\title{
THE EFFECT OF NOVEL MULTIWALLED CARBON NANOTUBE-TITANIA NANOTUBE HYBRID IN POLYAMIDE ACTIVE LAYER TOWARDS WATER PERMEABILITY AND HIGH SODIUM CHLORIDE REJECTION PERFORMANCE OF NANOFILTRATION MEMBRANE DESALINATION
}

\author{
(Kesan Hibrid Karbon Tiub Nano Pelbagai Dinding-Titania Tiub Nano Novel dalam Lapisan \\ Aktif Poliamida Terhadap Prestasi Kebolehtelapan Air dan Penyingkiran Natrium Klorida yang \\ Tinggi Bagi Membran Penapisan Nano Pengenyahmasin)
}

\author{
Ihsan Wan Azelee, Pei Sean Goh*, Woei Jye Lau, Ahmad Fauzi Ismail, Masood Rezaei Dasht Arzhandi, \\ Kar Chun Wong, Mahesan Naidu Subramaniam \\ Advanced Membrane Technology Research Centre (AMTEC), \\ Universiti Teknologi Malaysia, 81310 Skudai, Johor, Malaysia \\ *Corresponding author: peisean@petroleum.utm.my
}

Received: 26 August 2016; Accepted: 8 January 2017

\begin{abstract}
In this study, thin film nanocomposite (TFN) membranes were prepared by incorporating multi-walled carbon nanotube-titania nanotube (MWCNT-TNT) hybrid into the polyamide layer via interfacial polymerization on the surface of PS35 commercial substrate. The study showed that in the neat thin film composite (TFC), the presence of PIP in polyamide layer increased the water permeability (from 0.54 to $2.25 \mathrm{~L} / \mathrm{m}^{2} \mathrm{~h}$ bar) but decreased the $\mathrm{NaCl}$ rejection (from 86.48 to $47.45 \%$ ). Interestingly, the presence of MWCNT-TNT in MPD-PIP polyamide layer increased the $\mathrm{NaCl}$ rejection by $38.68 \%(47.45$ to $86.13 \%)$ while giving a significant water permeability performance at $0.86 \mathrm{~L} / \mathrm{m}^{2} \mathrm{~h}$ bar. The incorporation of acid treated MWCNT-TNT has improved the water permeability from 0.86 to $0.89 \mathrm{~L} / \mathrm{m}^{2} \mathrm{~h}$ bar while decreasing the $\mathrm{NaCl}$ rejection from 86.13 to $77.51 \%$. Further investigation of MWCNT-TNT loading at $\mathrm{pH} 2$ revealed that the increase of its loading in polyamide layer decreased both water permeability and $\mathrm{NaCl}$ rejection performance of the membrane. Overall, it can be concluded that the addition of an appropriate loading of surface modified MWCNT-TNT into the polyamide layer can remarkably improve the performance of conventional TFC membranes for desalination applications. In addition, incorporating PIP in the polyamide layer reduces the capability of the membrane on $\mathrm{NaCl}$ rejection.
\end{abstract}

Keywords: water desalination, thin film nanocomposite membrane, MWCNT-TNT hybrid

\begin{abstract}
Abstrak
Dalam kajian ini, filem nipis komposit nano (TFN) membran telah disediakan dengan menggabungkan karbon tiub nano pelbagai dinding-titania tiub nano (MWCNT-TNT) ke dalam lapisan poliamida melalui pempolimeran antara muka di permukaan substrat PS35 membran komersial. Kajian ini menunjukkan bahawa tanpa MWCNT-TNT, kehadiran PIP dalam lapisan poliamida meningkatkan kebolehtelapan air (daripada 0.54 kepada $2.25 \mathrm{~L} / \mathrm{m}^{2} \mathrm{~h}$ bar) tetapi mengurangkan penyingkiran $\mathrm{NaCl}$ (daripada 86.48 kepada 47.45\%). Menariknya, kehadiran MWCNT-TNT dalam lapisan poliamida MPD-PIP meningkatkan penyingkiran $\mathrm{NaCl}$ pada $38.68 \%$ (47.45 kepada $86.13 \%$ ) sambil memberi prestasi kebolehtelapan air yang besar pada $0.86 \mathrm{~L} / \mathrm{m}^{2}$ $\mathrm{h}$ bar. Penggabungan MWCNT-TNT ygng dirawat asid telah meningkat kebolehtelapan air dari 0.86 to $0.89 \mathrm{~L} / \mathrm{m}^{2} \mathrm{~h} \mathrm{bar}$ namun mengurangkan penyingkiran $\mathrm{NaCl}$ (daripada 86.13 kepada 77.51\%). Siasatan lanjut terhadap muatan MWCNT-TNT pada pH 2 mendedahkan bahawa peningkatan muatannya dalam lapisan poliamida menurun kedua-dua prestasi membran terhadap kebolehtelapan air dan penyingkiran $\mathrm{NaCl}$. Secara keseluruhan, dapat disimpulkan bahawa penambahan muatan dan $\mathrm{pH}$ yang
\end{abstract}


sesuai bagi MWCNT-TNT ke dalam lapisan poliamida dapat meningkatkan lagi prestasi membran TFC konvensional untuk aplikasi pengenyahmasin. Di samping itu, menggabungkan PIP dalam lapisan poliamida mengurangkan keupayaan membran terhadap penyingkiran $\mathrm{NaCl}$.

Kata kunci: pengenyahmasin air, membran filem nipis komposit nano, hibrid MWCNT-TNT

\section{Introduction}

Nanofiltration (NF) which lies between ultrafiltration (UF) and reverse osmosis (RO) is a separation technique used in desalination process mostly to reject multivalent ions rather than monovalent ions. NF shows some advantages over RO such as greater water permeability and lower operating pressure [1]. The thin film composite (TFC) NF membrane is normally fabricated through interfacial polymerization (IP) process of two immiscible phases in the formation of thin and dense polyamide layer. Nowadays, TFC NF membrane has also been widely applied for water purification, wastewater treatment, food processing and bio-separation [2].

Recently, many efforts have been made to tailor the structural properties of polyamide-based TFC membrane to improve the separation performance of the membrane. The introduction of polymeric nanocomposites either by mixed matrix membrane or incorporated in polyamide layer of the membrane have gained interest of many researchers. Various nanomaterials such as silica, zeolite, graphite, metal oxide nanomaterials and carbon nanotubes (CNTs) have been introduced for membrane application due to their unique features including the ability to promote high permeability and decreased in fouling resistance [3]. Evidently, each nano-materials have their own unique properties, but a single material is unlikely to simultaneously offer several if not all, of these beneficial features for membrane fabrication. This has led to recent developments and application of hybrid nanomaterials capable of synergistically contributing the advantages of their individual components and thereby reducing their shortcoming [4].

The present work aims to evaluate the feasibility of using multi-walled carbon nanotubes-titania (MWCNT-TNT) hybrid as nanofillers of thin film nanocomposite (TFN) membrane. Even though many works on inorganic nanoscale particles have been studied, however, there is still no exploration on hybrid nanomaterials for water desalination membrane. In this study, a hybrid of MWCNT-TNT will be incorporated into the polyamide layer of TFN membrane to harness the unique characteristic of both MWCNTs and TNTs. The TFN membrane will be evaluated in term of their water permeability and $\mathrm{NaCl}$ rejection performance.

\section{Materials}

\section{Materials and Methods}

Commercial ultrafiltration (UF) membrane obtained from Sterlitech was used for membrane substrate. 1,3,5benzenetricarboxylic acid chloride (TMC, Acros Organic) in n-hexane (Fisher Chemical), 1,3-phenylenediamine (MPD, Merck) and piperazine (PIP, Merck) in RO water were used in TFC membrane fabrication for PA layer. Titanium dioxide nanoparticles ( $\mathrm{TiO}_{2}$, Degussa P25 Evonik), multi-walled carbon nanotube (MWCNT, Aldrich), hydrochloric acid ( $\mathrm{HCl}$, Merck), sulfuric acid $\left(\mathrm{H}_{2} \mathrm{SO}_{4}\right.$, Merck $\left.95-97 \%\right)$, nitric acid $\left(\mathrm{HNO}_{3}, \mathrm{Merck}^{6} \%\right)$ and sodium hydroxide $(\mathrm{NaOH}$, Merck) and sodium hydroxide $(\mathrm{NaOH}$, Merck) were used to synthesize hybrid MWCNT-TNT. Sodium chloride ( $\mathrm{NaCl}$, Merck) was used in salt water preparation.

\section{Synthesis of MWCNT-TNT hybrid}

MWCNT-TNT hybrid was synthesized by oxidization and hydrothermal method. Firstly, $1 \mathrm{~g}$ of MWCNTs was acid refluxed in $\mathrm{H}_{2} \mathrm{SO}_{4}: \mathrm{HNO}_{3}$ (each $\left.3 \mathrm{M}, 3: 1, \mathrm{v} / \mathrm{v}\right)\left(250 \mathrm{ml}\right.$ ) at $80^{\circ} \mathrm{C}$ for 24 hours. The solution was filtered and washed to get $\mathrm{pH}$ neutral before oven-dried. $3 \mathrm{~g}$ of oxidized MWCNTs and $\mathrm{TiO}_{2}(1: 5)$ was undergone the hydrothermal process for 24 hours at $120{ }^{\circ} \mathrm{C}$ in $10 \mathrm{M} \mathrm{NaOH}(100 \mathrm{ml})$. The MWCNT-TNT was washed until pH lower than 9 and was treated with $\mathrm{HCl}$ solution $(0.1 \mathrm{M})$ to obtain $\mathrm{pH} 3-4$. The final product was washed to $\mathrm{pH}$ neutral and dried in an oven at $60^{\circ} \mathrm{C}$. To prepare the acid treated filler (a-MWCNT-TNT), the prepared MWCNT-TNT was treated with hydrochloric acid ( $\mathrm{HCl}$ ). Briefly, a $0.2 \mathrm{~g}$ of MWCNT-TNT was added into a solution of $\mathrm{pH} 2 \mathrm{containing} 0.05 \mathrm{HCl}$ solution and was shake for 24 hours. All the solution were prepared with a specific gravity of $0.03 \mathrm{M} \mathrm{NaCl}$ solutions as buffer solution. The precipitate of a-MWCNT-TNT was filtered and dried in the oven at $60{ }^{\circ} \mathrm{C}$ [5]. 


\section{Synthesis of polyamide layer}

Two types of polyamide layer were formed by (i) MPD (1.5wt) / TMC $(0.05 \mathrm{wt})$ which indicated as TFC A and (ii) MPD (1.13wt)-PIP (0.37wt) / TMC (0.05wt) indicated as TFC B. The polyamide layer for thin film composite (TFC) membrane was introduced via interfacial polymerization (IP) process on the surface of PS35 substrate membrane. The PS35 substrate was kept in RO water for at least 24 hours prior to interfacial polymerization (IP) process. Briefly, the MPD or MPD-PIP, was dissolved in RO water and the solution was covered by tissue paper to prevent from light oxidation [6]. In separated solution, TMC was dissolved in n-hexane. All the solutions were stirred at a minimum of 3 hours prior to use. To begin IP process, $40 \mathrm{ml}$ of MPD aqueous solution ( $0.8 \mathrm{~g}$ MPD in 40 $\mathrm{ml}$ RO water) was poured and fully covered the PS35 substrate surface which was held horizontally for $1 \mathrm{~min}$. The excess MPD solution and residual droplets were gently removed by using a soft rubber roller. Then, $40 \mathrm{ml}$ of TMC solution ( $0.04 \mathrm{~g}$ TMC in $40 \mathrm{ml} \mathrm{n}$-hexane) was also poured and fully covered on the substrate and was drained off after $50 \mathrm{~s}$. The synthesized TFC membrane was dried for $1 \mathrm{~min}$ at ambient condition and 5 min later in the oven at $65^{\circ} \mathrm{C}$. Finally, the TFC membrane was cooled for $1 \mathrm{~min}$ at ambient condition before continued to be rinsed with water and stored in RO water container [7]. The membrane (mentioned as MWCNT-TNT/TFC) were fabricated similarly to TFC membrane, except that during the interfacial polymerization, the MWCNT-TNT $(0.05 \mathrm{wt} . \%$ or 0.1 wt.\%) was dispersed and sonicated for $30 \mathrm{~min}$ in organic solution of TMC in n-hexane and was reacted with MPD or MPD-PIP immobilized on PS35 substrate commercial membrane

\section{Characterization of MWCNT-TNT, TFC and TFN membranes}

The crystal configuration of MWCNT-TNT hybrid was analyzed by X-ray diffraction (XRD) analysis. The tabular morphology of MWCNT-TNT hybrid was observed by transmission electron microscopy (TEM, HT 7700, Hitachi). The Zeta potential analysis (Malvern Zetasizer, Nano ZS) was utilized to determine the charge of the MWCNTTNT and fabricated membrane. The hydrophilicity of membranes was measured by contact angle goniometer (OCA 15Pro, Dataphysics).

\section{Performance study of TFC and TFN membranes}

Pure water permeability and salt rejection performance by RO water and standard aqueous solution of $\mathrm{NaCl}$ (2000ppm) were conducted using dead end RO cell at an applied pressure of 15 bar. All permeation experiments were performed using circular membranes with an effective area of $14.6 \mathrm{~cm}^{2}$. The membrane water permeability was evaluated by dividing the water flux value (Eq. 1) with operating pressure (15 bar).

$$
J=\frac{V}{A \times t}
$$

where $V$ is the permeate volume (L), $A$ is the membrane active area $\left(\mathrm{m}^{2}\right)$ and $t$ is the experiment time (h) to obtain $V$. The salt rejection was calculated based on following Equation 2:

$$
R(\%)=\left(1-\frac{C_{p}}{C_{f}}\right) \times 100
$$

where $C_{p}$ and $C_{f}$ are the concentration (ppm) of the permeate and feed solution, respectively.

\section{XRD analysis}

\section{Results and Discussion}

The XRD analysis of MWCNT-TNT hybrid, MWCNTs and TNTs are represented in Figure 1. The self-synthesized TNTs sample shows an intense peak at 2-theta values of $10.48^{\circ}, 24.76^{\circ}$ and $48.58^{\circ}$. These patterns correspond to the crystal structure of TNTs. The peaks at a 2-theta values of $25.78^{\circ}$ and $43.13^{\circ}$ in XRD pattern of MWCNTs correspond to the cylindrical concentric tubular structure of MWCNTs and the $\mathrm{sp}^{3}$ hybridization of the carbon atom. The characterization peak of MWCNTs at $25.78^{\circ}$ can also be observed clearly in the formation peak at $26.18^{\circ}$ in the patterns of MWCNT-TNT hybrid, which suggested the successful formation of MWCNT-TNTs [8]. Meanwhile, an intense peak at 2-theta values of $24.98^{\circ}, 26.18^{\circ}$ and $48.72^{\circ}$ for MWCNT-TNT hybrid samples supported the 
Ihsan et al: THE EFFECT OF NOVEL MULTIWALLED CARBON NANOTUBE-TITANIA NANOTUBE HYBRID IN POLYAMIDE ACTIVE LAYER TOWARDS WATER PERMEABILITY AND HIGH SODIUM CHLORIDE REJECTION PERFORMANCE OF NANOFILTRATION MEMBRANE DESALINATION

formation of TNTs nanotubes. The diffraction peak $10.48^{\circ}$ and $11.1^{\circ}$ showed by TNTs and MWCNT-TNT hybrid, respectively, a notable feature of the tubular structure of $\mathrm{TiO}_{2}$ nanomaterials [8].

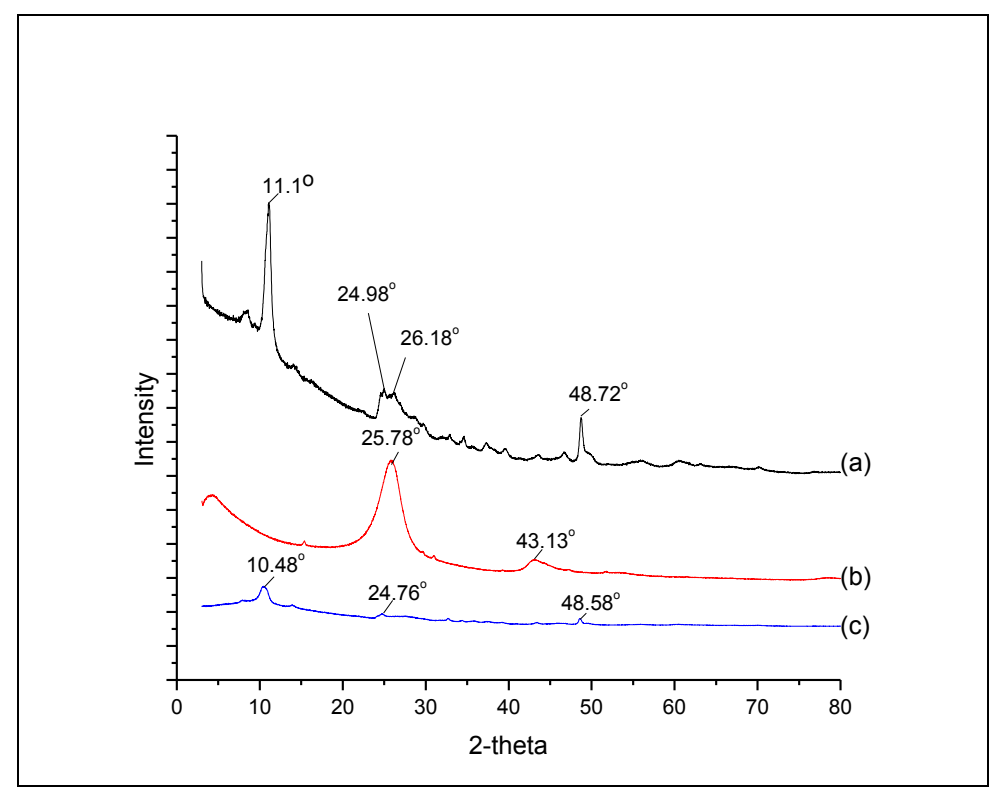

Figure 1. XRD patterns of (a) self-synthesized MWCNT-TNT hybrid, (b) commercial MWCNTs and (c) selfsynthesized TNT

\section{TEM analysis}

TEM images (Figure 2) clearly demonstrate the tubular structure of MWCNT-TNT hybrid which depicted the open end of MWCNTs in the MWCNT-TNT hybrid. The MWCNT have the outer diameter in the range of $16-20 \mathrm{~nm}$ while $71-141 \mathrm{~nm}$ for TNT, as indicated by TEM image. In addition, there were no $\mathrm{TiO}_{2}$ nanoparticles (NPs) observed in TEM image of MWCNT-TNT hybrid, confirming that $\mathrm{TiO}_{2} \mathrm{NPs}$ was completely converted into TNTs after the hydrothermal treatment. These findings are consistent with the XRD results. Liu et al. [8],who applied the same hydrothermal method for the synthesized of MWCNT-TNT hybrid indicated the homogeneous mixture of nanotube was difficult to be achieved through the simple mechanical mixing.

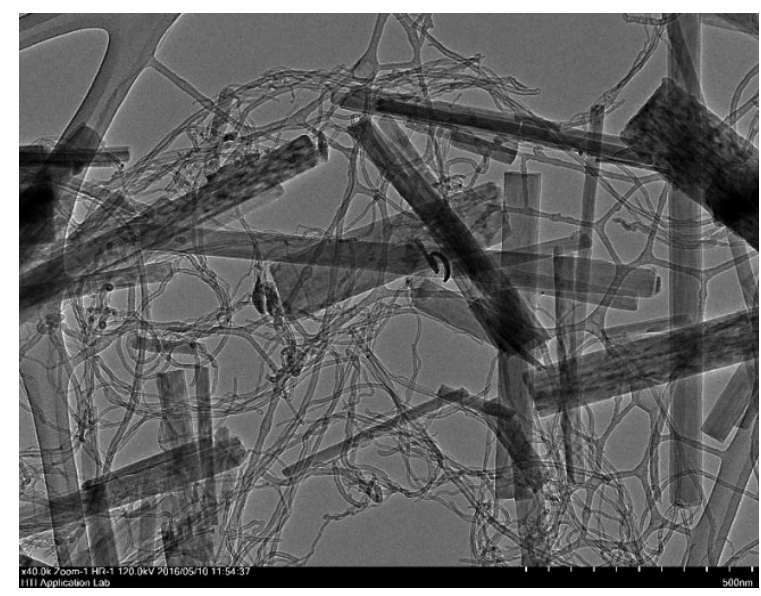

Figure 2. TEM image (magnification: 40K) of MWCNT-TNT hybrid 


\section{Membrane performance}

Water permeability and $\mathrm{NaCl}$ rejection were evaluated for the membrane performance to determine the effect of the addition of MWCNT-TNT hybrid as nanofiller in polyamide layer of composite membrane. It was observed (Figure 3) that the water permeability of TFC membrane was increased from 0.54 to $2.25 \mathrm{~L} / \mathrm{m}^{2} \mathrm{~h}$ bar when piperazine as a co-monomer was used in polyamide selective layer (TFC B). The transport property that includes flux and rejection of nanofiltration membranes were greatly influenced by monomer type during polyamide layer formation which in accordance with that reported Saha and Joshi [9]. It was also believed that the addition of piperazine into PA layer will disturb the restricted chain flexibility of MPD-TMC PA, resulting in high water permeability in TFC B [9].

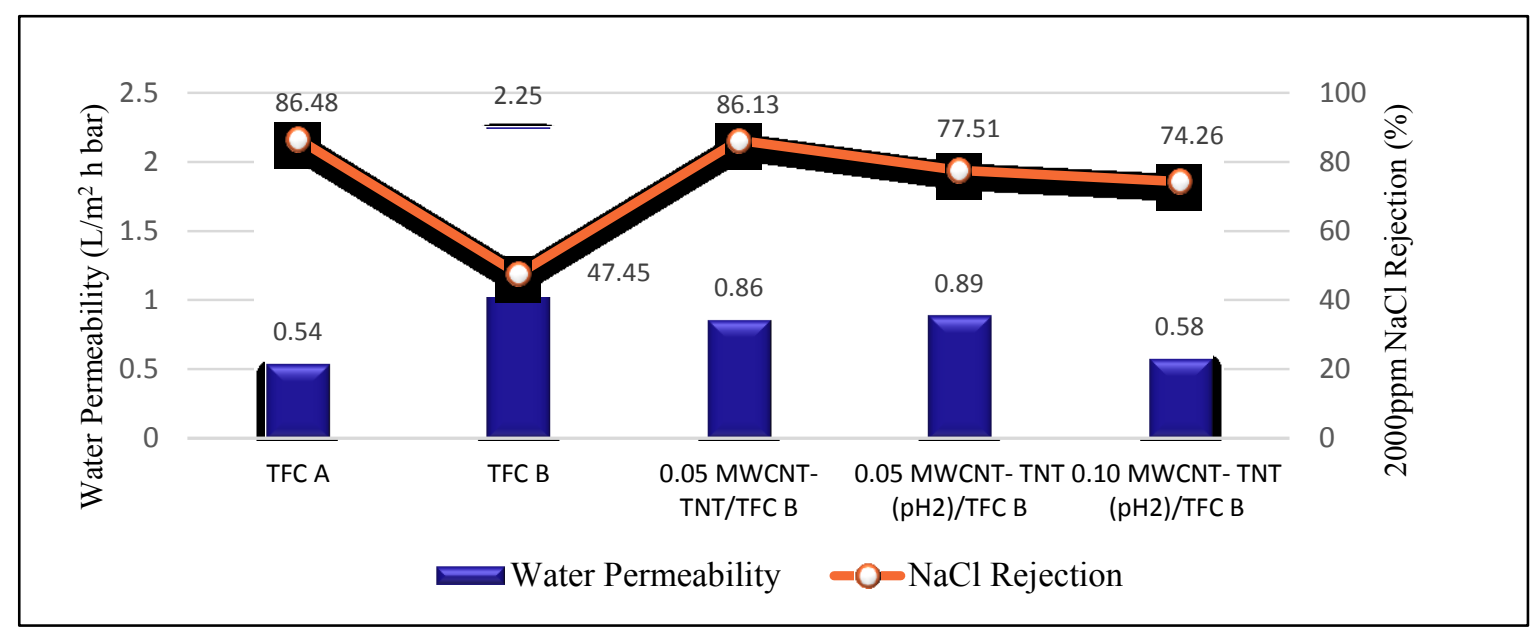

Figure 3. Water permeability and $\mathrm{NaCl}$ separation of thin film composite membranes (TFC) of TFC A [MPD (1.5wt) / TMC (0.05wt)] and TFC B [MPD (1.13wt)-PIP (0.37wt) / TMC (0.05wt)]. (Test conditions: 15 bar, $25^{\circ} \mathrm{C}, 2000 \mathrm{ppm} \mathrm{NaCl}$ aqueous solution)

However, the sharp increase in water permeability deteriorating the $\mathrm{NaCl}$ rejection from $86.48 \%$ to $47.45 \%$. This observation is in agreement with that of reported by Wu et al. [1] where PIP was used as co-monomer. Uniquely, by incorporating the MWCNT-TNT hybrid in TFC B, the $\mathrm{NaCl}$ rejection increased from $47.45 \%$ to $86.13 \%$, while the water permeability was higher compared to TFC A. The existence of hydrogen on MWCNT-TNT can enhance the hydrogen bonding formation in PA layer which in turn decreased the pore sizes in PA layer while later contributed to low water permeability and increase $\mathrm{NaCl}$ rejection [9]. Moreover, the successful synthesis of MWCNT-TNT as confirmed by XRD and TEM provides unique properties for the membrane which offers pore channels and high hydrophilicity of hybrid to increase water permeability while reject certain dissolved ions [10], [11]. Meanwhile, when the MWCNT-TNT was treated with acid (a-MWCNT-TNT) and was incorporated into the polyamide layer of TFC B, the water permeability was increased as indicated by decreasing contact angle from 72.92 to $61.71^{\circ}$ of the membrane as shown in Table 1.

However, a-MWCNT-TNT/TFC B showed a slightly decreased in $\mathrm{NaCl}$ rejection. The polymer links formed from PIP and TMC, which occurs faster in polyamide layer of TFC B might compete with the bonding between aMWCNT-TNT with the free $-\mathrm{COCl}$ groups of TMC [1]. Hence, contributed to the decreased in surface negative charge of the membrane as provided by the positive value of zeta potential (Table 1). The further increased of aMWCNT-TNT in polyamide layer of TFC B deteriorated $\mathrm{NaCl}$ rejection of membrane performance. It is possibly due to the tendency of $\mathrm{NaCl}$ molecules to pass through some voids between a-MWCNT-TNT and polyamide at high loading of the hybrid nanotube [11]. Moreover, higher a-MWCNT-TNT loading (0.10 MWCNT-TNT) led to ineffectiveness on water permeability, which likely suggests the formation of thicker polyamide rejection layer under this a-MWCNT-TNT loading condition $[12,13]$. 
Ihsan et al: THE EFFECT OF NOVEL MULTIWALLED CARBON NANOTUBE-TITANIA NANOTUBE HYBRID IN POLYAMIDE ACTIVE LAYER TOWARDS WATER PERMEABILITY AND HIGH SODIUM CHLORIDE REJECTION PERFORMANCE OF NANOFILTRATION MEMBRANE DESALINATION

Table 1. The properties of MWCNT-TNT hybrid and TFC/TFN membranes prepared in this work

\begin{tabular}{lcc}
\hline MWCNT-TNT / Membrane & $\begin{array}{c}\text { Contact Angle } \\
(\mathbf{(})\end{array}$ & $\begin{array}{c}\text { Surface Zeta Potential } \\
(\mathbf{m V})\end{array}$ \\
\hline MWCNT-TNT & - & -8.95 \\
a-MWCNT-TNT & - & 26.6 \\
TFC A & $90.22 \pm 2.81$ & - \\
TFC B & $52.66 \pm 3.39$ & -14.1 \\
0.05 MWCNT-TNT/TFC B & $72.92 \pm 3.56$ & -10.6 \\
0.05 a-MWCNT-TNT/TFC B & $61.71 \pm 2.21$ & 17.2 \\
0.10 a-MWCNT-TNT/TFC B & $75.77 \pm 2.97$ & 14.3 \\
\hline
\end{tabular}

\section{Conclusion}

Novel TFN membranes for nanofiltration were fabricated by incorporating MWCNT-TNT hybrid. The MWCNTTNT hybrid was successfully synthesized, which was confirmed by XRD and TEM analysis. The mixed crosslinking of MPD-PIP diamine monomer during interfacial polymerization in polyamide layer decreased the rejection of $\mathrm{NaCl}$ to an average of $39 \%$. The unique properties of MWCNT-TNT hybrid such as tubular structure have improved the membrane performance in terms of water permeability and $\mathrm{NaCl}$ rejection. The acid treatment of MWCNT-TNT with $\mathrm{HCl}$ possibly provided external $\mathrm{Cl}$ group which help on PA layer formation. However, it might compete with the fast reaction of PIP monomer which decrease the negative charge of the membrane and decreased the salt rejection. Worth noting that the higher loading of a-MWCNT-TNT in MPD-PIP polyamide layer decreased both water permeability and $\mathrm{NaCl}$ rejection of membrane performance due to the dense PA layer formation.

\section{Acknowledgement}

The authors would like to acknowledge the financial supports provided by Ministry of Higher Education (FRGS Grant: 4F306 and HiCOE Grant: 4J196) and Universiti Teknologi Malaysia for Research University Grant: 02G43. Author, Ihsan Wan Azelee thanks the sponsorship given by Ministry of Higher Education under MyBrain15 (MyPhD) scheme during his Ph.D. studies.

\section{References}

1. Wu, D., Yu, S., Lawless, D. and Feng, X. (2015). Thin film composite nanofiltration membranes fabricated from polymeric amine polyethylenimine imbedded with monomeric amine piperazine for enhanced salt separations. Reactive and Functional Polymers, 86: 168 - 1835.

2. Lau, W. J., Ismail, A. F., Goh, P. S., Hilal, N. and Ooi, B. S. (2014). Characterization methods of thin film composite nanofiltration membranes. Separation and Purification Reviews, 44 (2): 135 - 156.

3. Vatanpour, V., Esmaeili, M. and Farahani, M. H. D. A. (2014). Fouling reduction and retention increment of polyethersulfone nanofiltration membranes embedded by amine-functionalized multi-walled carbon nanotubes. Journal of Membrane Science, 466: 70 - 81.

4. Natarajan, T. S., Lee, J. Y., Bajaj, H. C., Jo, W.-K. and Tayade, R. J. (2016). Synthesis of multiwall carbon nanotubes $/ \mathrm{TiO}_{2}$ nanotube composites with enhanced photocatalytic decomposition efficiency. Catalysis Today, 282: $13-23$.

5. Mudunkotuwa, I. A. and Grassian, V. H. (2010). Citric acid adsorption on $\mathrm{TiO}_{2}$ nanoparticles in aqueous suspensions at acidic and circumneutral $\mathrm{pH}$ : Surface coverage, surface speciation, and its impact on nanoparticle - nanoparticle interactions. Jounal of American Chemical Society, 132: 14986 - 14994.

6. Lind, M. L., Suk, D. E., Nguyen, T. V. and Hoek, E. M. V. (2010). Tailoring the structure of thin film nanocomposite membranes to achieve seawater RO membrane performance. Environmental Science and Technology, 44 (21): $8230-8235$.

7. Xie, W., Geise, G. M., Freeman, B. D., Lee, H. S., Byun, G. and McGrath, J. E. (2012). Polyamide interfacial composite membranes prepared from m-phenylene diamine, trimesoyl chloride and a new disulfonated diamine. Journal of Membrane Science, 403 - 404: 152 - 161. 
8. Liu, X., Yan, R., Zhang, J., Zhu, J. and Wong, D. K. Y. (2015). Evaluation of a carbon nanotube-titanate nanotube nanocomposite as an electrochemical biosensor scaffold. Biosensors and Bioelectronics, 66: 208 215.

9. Saha, N. K. and Joshi, S. V. (2009). Performance evaluation of thin film composite polyamide nanofiltration membrane with variation in monomer type. Journal of Membrane Science, 342 (1-2): 60 - 69.

10. Daer, S., Kharraz, J., Giwa, A. and Hasan, S. W. (2015). Recent applications of nanomaterials in water desalination: A critical review and future opportunities. Desalination, 367: $37-48$.

11. Zhang, L., Shi, G.-Z., Qiu, S., Cheng, L.-H. and Chen, H.-L. (2011). Preparation of high-flux thin film nanocomposite reverse osmosis membranes by incorporating functionalized multi-walled carbon nanotubes. Desalination and Water Treatment, 34(1-3): $19-24$.

12. Ma, N., Wei, J., Liao, R. and Tang, C. Y. (2012). Zeolite-polyamide thin film nanocomposite membranes: Towards enhanced performance for forward osmosis. Journal of Membrane Science, 405 - 406: 149 - 157.

13. Wan Azelee, I., Goh, P. S., Lau, W. J., Ng, B. C. and Ismail, A. F. (2016). Development of thin film nanocomposite embedded with graphene oxide for $\mathrm{MgSO}_{4}$ removal. Journal of Engineerning Science and Technology, 11(7): $974-986$. 